OPEN ACCESS

Edited by:

Carmine Gaeta,

University of Salerno, Italy

Reviewed by:

Paula M. Marcos,

University of Lisbon, Portugal

Silvano Geremia

University of Trieste, Italy

*Correspondence:

Andrea Pappalardo

andrea.pappalardo@unict.it

Specialty section:

This article was submitted to

Supramolecular Chemistry,

a section of the journal

Frontiers in Chemistry

Received: 27 September 2019

Accepted: 18 November 2019

Published: 03 December 2019

Citation:

Gangemi CMA, Rimkaite U, Cipria F, Trusso Sfrazzetto $G$ and Pappalardo A

(2019) Enantiomeric Recognition of $\alpha$-Aminoacids by a Uranyl

Salen-Bis-Porphyrin Complex.

Front. Chem. 7:836.

doi: 10.3389/fchem.2019.00836

\section{Enantiomeric Recognition of $\alpha$-Aminoacids by a Uranyl Salen-Bis-Porphyrin Complex}

\author{
Chiara M. A. Gangemi ${ }^{1}$, Ugne Rimkaite ${ }^{2}$, Federica Cipria ${ }^{1}$, Giuseppe Trusso Sfrazzetto ${ }^{1,3}$ \\ and Andrea Pappalardo ${ }^{1,3 *}$
}

${ }^{1}$ Department of Chemical Sciences, University of Catania, Catania, Italy, ${ }^{2}$ Faculty of Chemistry and Geosciences, University of Vilnius, Vilnius, Lithuania, ${ }^{3}$ I.N.S. T.M. - Consorzio Interuniversitario Nazionale per la Scienza e Tecnologia dei Materiali, University of Catania, Catania, Italy

A novel uranyl salen-bis-porphyrin complex, in which two porphyrin subunits and salen moiety were directly linked, was synthesized for the recognition of tetrabutylammonium (TBA) amino acids. This uranyl salen complex, due to the presence of porphyrins with their fluorescence properties, represents the first example of a luminescence of uranyl salen complexes. UVNis measurements indicate the formation of 1:1 host-guest complexes, whereas UV-vis and fluorescence studies revealed that this complex acts as a receptor for the enantiomeric recognition of $\alpha$-aminoacids derivatives, with high association constants and an excellent enantiomeric discrimination between the two enantiomers of phenylalanine-TBA.

Keywords: porphyrins, salen ligands, uranyl complexes, luminescence, enantiomeric recognition

\section{INTRODUCTION}

Salen ligands are a class of molecules that have been widely explored in the field of supramolecular chemistry. The most fascinating and promising use of salen derivatives is due to their chiral complexes with numerous metals. The salen structure, due to two contiguous stereogenic carbon atoms in the diimine bridge, creates a chiral pocket which can coordinate a metal cation (via imine nitrogen and phenolic oxygen atoms). Salen ligands rose to prominence thanks to the pioneering work of Jacobsen and Katsuki that paved the way to one of the most well-designed protocol for the enantioselective epoxidation of unfunctionalized alkenes catalyzed by chiral manganese salen complexes (Jacobsen, 1993; Katsuki, 2000; Yoon and Jacobsen, 2003; La Paglia Fragola et al., 2012; Trusso Sfrazzetto et al., 2015; Ballistreri et al., 2016, 2018; Zammataro et al., 2019). Furthermore, salen ligands are structures of great value in homogeneous catalysis (Katsuki, 1995; Jacobsen, 2000; Cozzi, 2004; McGarrigle and Gilheany, 2005; Baleizao and Garcia, 2006; Wezenberg and Kleij, 2008; Whiteoak et al., 2012).

In recent years, our research group exploited these chiral salen-metal complexes as enantiomeric receptors for chiral guests. In fact, depending on the metal ion and different substituents in the aromatic ring of salen framework, these salen-metal complexes can be used as efficient enantioselective catalysts and highly sensitive chemosensors (D'Urso et al., 2014; Puglisi et al., 2017, 2018, 2019). In particular, chiral uranyl salen complexes have proved to be excellent receptors for amino acid salts (Amato et al., 2007, 2010, 2011; Ballistreri et al., 2010; Pappalardo et al., 2012a), since the uranyl metal center, acting as a Lewis acid, possesses an equatorial fifth position able to coordinate one molecule of carboxylate anion (Ballistreri et al., 2012; Brancatelli et al., 2013). These synthetic enantioselective receptors could help to better understand the mechanisms of drugs action; processes that are involved in immunological responses and processes of the storage of 
genetic information. Besides, slightly modification of their structures could lead to chemosensors, which due to their simple use, relatively low cost and high sensitivity are particularly significant in the chemical analysis.

Taking into account the salen ligand applications in the field of catalysis and enantiomeric recognition, previous studies have inspired us to extend current research on the synthesis of salen receptors comprising porphyrin macrocycles which, with their high stability and fluorescence properties, could greatly extend the use of salen ligands as chemosensors. Porphyrins, due to their rigid molecular structure, tunable substituents, large skeleton dimensions, and additional metallation sites in the core, are very attractive macrocycles for their applications in many technological fields (Beletskaya et al., 2009; Drain et al., 2009). In our strategy, the rational combination of porphyrin derivatives with chiral uranyl-salen ligands in one structure, would lead to chemosensors that possess unprecedented luminescence properties, that till now were precluded in uranyl-salen complexes due to the presence of uranyl metal center. Here we report on the synthesis of a novel uranyl salen-bis-porphyrin complex, in which two porphyrin subunits and the salen ligand are directly connected, and the enantiomeric recognition properties of this receptor toward selected $\alpha$ aminoacids derivatives assessed by UV-vis and fluorescence measurements (Figure 1).

\section{MATERIALS AND METHODS}

\section{General Experimental Methods}

The NMR experiments were carried out at $27^{\circ} \mathrm{C}$ on a Varian UNITY Inova $500 \mathrm{MHz}$ spectrometer $\left({ }^{1} \mathrm{H}\right.$ at 499.88 $\mathrm{MHz},{ }^{13} \mathrm{C} \mathrm{NMR}$ at $125.7 \mathrm{MHz}$ ) equipped with pulse field gradient module ( $Z$ axis) and a tuneable $5 \mathrm{~mm}$ Varian inverse detection probe (ID-PFG). ESI mass spectra were acquired on a API 2000- ABSciex using $\mathrm{CH}_{3} \mathrm{OH}$ (positive ion mode). A JASCO V-560 UV-Vis spectrophotometer equipped with a $1 \mathrm{~cm}$ path-length cell was used for the UV-Vis measurements. Luminescence measurements were carried out using a Cary Eclipse Fluorescence spectrophotometer with resolution of $0.5 \mathrm{~nm}$, at room temperature. The emission was recorded at $90^{\circ}$ with respect to the exciting line beam using 10:10 slit-widths for all measurements. All chemicals were reagent grade and were used without further purification.

\section{General Procedure for the Synthesis of TBA Amino Acid Derivates (Ballistreri et al., 2010)}

An aqueous solution of tetrabutylammonium hydroxide (40\% $\mathrm{w} / \mathrm{w}, 13 \mathrm{mmol}$ ) was added to an aqueous suspension of the desired amino acid $(13 \mathrm{mmol})$. The resultant reaction mixture was heated at $60^{\circ} \mathrm{C}$ for $2 \mathrm{~h}$. Water was removed in vacuo at $80^{\circ} \mathrm{C}$. The residue was dissolved in $\mathrm{CH}_{2} \mathrm{Cl}_{2}(10 \mathrm{~mL})$, filtered and the solvent was evaporated in vacuo to afford in high yield the desired product.

\section{Procedure for UV-vis and Fluorescence Titrations}

Two stock solutions of host and guest $\left(1.0 \times 10^{-3} \mathrm{M}\right)$ in dry chloroform were prepared. From these, different solutions with different ratio receptor/guest (host concentration $=1.0$ $\times 10^{-6} \mathrm{M}$ ) were prepared, and UV-vis and emission spectra were recorded at $25^{\circ} \mathrm{C}$. Fluorescence titrations were carried out using $\lambda_{\text {ex }}=350 \mathrm{~nm}$ in dry chloroform, recording at $\lambda_{\mathrm{em}}=650$ and $715 \mathrm{~nm}$. With this data treatment, the apparent binding affinities of receptor with amino acid guests were estimated using HypSpec (version 1.1.33) (Pappalardo et al., 2012b), a software designed to extract equilibrium constants from potentiometric and/or spectrophotometric titration data. HypSpec starts with an assumed complex formation scheme and uses a least-squares approach to derive the spectra of the complexes and the stability constants. $\chi^{2}$-test (chi-square) was applied, where the residuals follow a normal distribution (for a distribution approximately normal, the $\chi^{2}$-test value is around 12 or less). In all of the cases, $\chi^{2} \leq 10$ were found, as obtained by 3 independent measurement sets.

\section{Synthesis of Compound 4 (Johansson et al., 2003)}

$5.0 \mathrm{~g}(0.0300 \mathrm{~mol})$ of compound 2 (Dalla Cort et al., 2006) and $5.97 \mathrm{~g}$ of potassium phthalimide $3(0.0322 \mathrm{~mol})$ were placed in a $250 \mathrm{~mL}$ round-bottom flask. The reagents were dissolved in $100 \mathrm{~mL}$ of DMF. The reaction mixture was allowed to stir at room temperature for $48 \mathrm{~h}$ and then was heated at $55^{\circ} \mathrm{C}$ for $4 \mathrm{~h}$. The reaction mixture was cooled down to room temperature and diluted with $250 \mathrm{~mL}$ of EtOAc and washed with water $(3 \times$ $200 \mathrm{~mL}$ ). The organic layer was dried over anhydrous $\mathrm{Na}_{2} \mathrm{SO}_{4}$, filtered and evaporated. The product was purified by silica gel column chromatography $\left(\mathrm{CHCl}_{3}\right)$ to afford $3.37 \mathrm{~g}$ (40\% yield) of compound 4. ${ }^{1} \mathrm{H}$ NMR (500 MHz, $\left.\mathrm{CDCl}_{3}\right): \delta=10.99(\mathrm{~s}, 1 \mathrm{H})$; 9.88 (s, 1H); 7.86-7.84 (m, 2H); 7.73-7.71 (m, 2H); $7.67(\mathrm{~s}, 1 \mathrm{H})$; $7.65-7.63(\mathrm{dd}, J=8.5 \mathrm{~Hz}, J=2.0 \mathrm{~Hz}, 1 \mathrm{H}) ; 6.95(\mathrm{~d}, J=8.5 \mathrm{~Hz}$, $1 \mathrm{H}) ; 4.82$ (s, 2H).

\section{Synthesis of Compound 5}

$0.662 \mathrm{~g}$ ( $2.36 \mathrm{mmol})$ of compound 4 and $0.0171 \mathrm{~g}(0.036 \mathrm{mmol})$ of tetrabutylammonium tribromide were placed in a $20 \mathrm{~mL}$ round-bottom flask. In this flask $3.60 \mathrm{~mL}$ of 1,3-propanediol and $3.90 \mathrm{~mL}$ of triethyl orthoformate were added. The reaction mixture was allowed to stir at room temperature for $48 \mathrm{~h}$, then diluted with $45 \mathrm{~mL}$ of EtOAc. The organic solution was washed with water $(3 \times 20 \mathrm{~mL})$, dried over anhydrous $\mathrm{Na}_{2} \mathrm{SO}_{4}$, filtered and evaporated. The product was purified by silica gel column chromatography (cyclohexane/EtOAc 3:1) affording $0.732 \mathrm{~g}$ of white compound 5 (92\% yield). ${ }^{1} \mathrm{H} \mathrm{NMR}\left(500 \mathrm{MHz}^{\mathrm{CDCl}} 3\right): \delta=$ 7.85 (s, 1H); 7.83-7.81 (m, 2H); 7.70-7.68 (m, 2H); 7.36-7.34 (dd, $J=8.5 \mathrm{~Hz}, J=2.5 \mathrm{~Hz}, 1 \mathrm{H}) ; 7.28(\mathrm{~s}, 1 \mathrm{H}) ; 6.84(\mathrm{~d}, J=8.5 \mathrm{~Hz}, 1 \mathrm{H})$; $5.61(\mathrm{~s}, 1 \mathrm{H}) ; 4.74(\mathrm{~s}, 2 \mathrm{H}) ; 4.30-4.27(\mathrm{~m}, 2 \mathrm{H}) ; 4.02-3.96(\mathrm{~m}, 2 \mathrm{H})$; $2.30-2.20(\mathrm{~m}, 1 \mathrm{H}) ; 1.52-1.48(\mathrm{~m}, 1 \mathrm{H}) .{ }^{13} \mathrm{C}\left(125 \mathrm{MHz}, \mathrm{CDCl}_{3}\right)$ : $\delta=25.6,31.4,40.9,67.2,102.9,117.4,122.1,123.2,127.6,128.6$, $131.3,132.1,133.9,154.9,168.0$. 


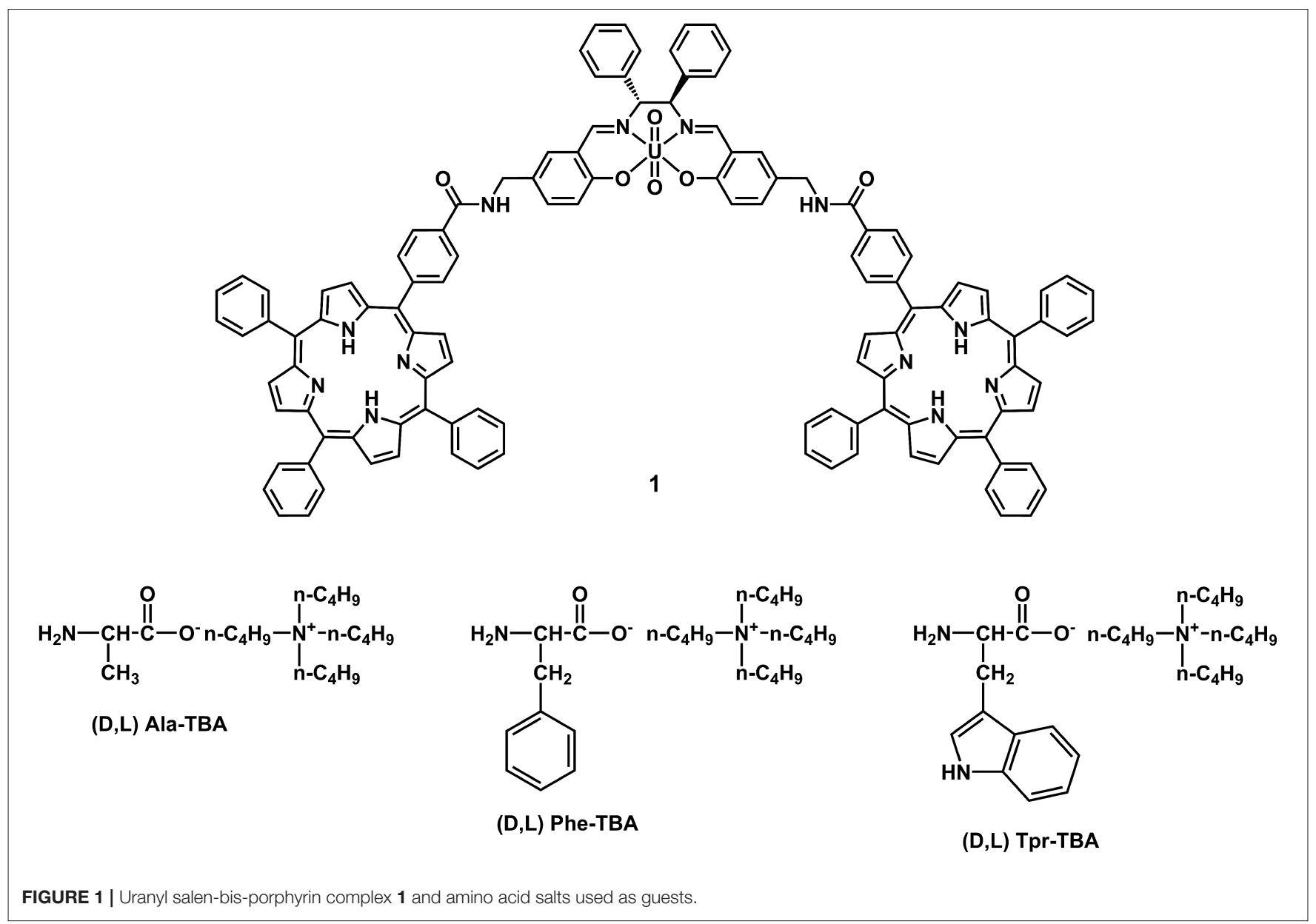

\section{Synthesis of Compound 6}

$0.440 \mathrm{~g}(1.298 \mathrm{mmol})$ of compound 5 and $0.704 \mathrm{~mL}(0.713 \mathrm{mmol})$ of hydrazine monohydrate in $30 \mathrm{~mL}$ of $\mathrm{EtOH}$ were added in a round-bottomed flask of $50 \mathrm{~mL}$. The reaction was heated at $90^{\circ} \mathrm{C}$ and monitored by TLC. After $20 \mathrm{~min}$, the heating was interrupted. The reaction mixture was cooled down to room temperature and solvent was evaporated. The obtained white precipitate was diluted in $30 \mathrm{~mL}$ of water. The aqueous solution was extracted with $\mathrm{CHCl}_{3}(2 \times 20 \mathrm{~mL})$ which was previously passed through $\mathrm{Al}_{2} \mathrm{O}_{3}$ layer. The $\mathrm{CHCl}_{3}$ solution was dried over anhydrous $\mathrm{Na}_{2} \mathrm{SO}_{4}$, filtered and evaporated. Compound 6 $(0.154 \mathrm{~g}, 57 \%)$ was obtained as a yellow oil. ${ }^{1} \mathrm{H} \mathrm{NMR}(500 \mathrm{MHz}$, $\left.\mathrm{CDCl}_{3}\right): \delta=7.18-7.16(\mathrm{dd}, J=8.5 \mathrm{~Hz}, J=2.0 \mathrm{~Hz}, 1 \mathrm{H}) ; 7.14(\mathrm{~s}$, $1 \mathrm{H})$; $6.87-6.85(\mathrm{~d}, J=8.5 \mathrm{~Hz}, 1 \mathrm{H}) ; 5.65(\mathrm{~s}, 1 \mathrm{H}) ; 4.33-4.30(\mathrm{~m}, 2 \mathrm{H})$; 4.04-3.99 (m, 2H); 3.77 (s, 2H); 2.32-2.30 (m, 1H); 1.54-1.50 (m, 1H). ${ }^{13} \mathrm{C}$ NMR $\left(125 \mathrm{MHz}, \mathrm{CDCl}_{3}\right): 26.6 ; 45.7 ; 67.4 ; 102.4 ; 117.1$; $122.2 ; 126.3 ; 129.2 ; 134.3 ; 154.0$.

\section{Synthesis of Compound 8}

$0.394 \mathrm{~g}(0.598 \mathrm{mmol})$ of compound 7 (Gaware et al., 2017) were dissolved in $20 \mathrm{~mL}$ of anhydrous DMF, in a round-bottomed flask. To this stirred solution $0.273 \mathrm{~g}(0.718 \mathrm{mmol})$ of HATU was added, and the resulting mixture was left to stir under $\mathrm{N}_{2}$ atmosphere at room temperature for $20 \mathrm{~min}$. Then, solution of $0.130 \mathrm{~g}(0.623 \mathrm{mmol})$ of compound 6 in $5 \mathrm{~mL}$ of anhydrous DMF was poured into the reaction mixture, which was stirred under $\mathrm{N}_{2}$ atmosphere and room temperature, for other $40 \mathrm{~min}$. Finally, $0.105 \mathrm{~mL}(0.623 \mathrm{mmol})$ of $N^{\prime} N$-diisopropylethylamine was added to the reaction mixture. The reaction was carried out in $\mathrm{N}_{2}$ atmosphere for $70 \mathrm{~h}$. After this period, the reaction mixture was evaporated. The resulting precipitate was dissolved in $30 \mathrm{~mL}$ of $\mathrm{CH}_{2} \mathrm{Cl}_{2}$. The organic solution was washed with water $(3 \times 40 \mathrm{~mL})$, dried over anhydrous $\mathrm{Na}_{2} \mathrm{SO}_{4}$ filtered and evaporated. Compound $\mathbf{8}$ was purified by silica gel column chromatography $\left(\mathrm{CH}_{2} \mathrm{Cl}_{2} / \mathrm{MeOH} 100: 2\right)$ affording $80 \mathrm{mg}(16 \%$ yield) of a purple solid. ${ }^{1} \mathrm{HNMR}\left(500 \mathrm{MHz}, \mathrm{CDCl}_{3}\right): \delta=8.85-$ $8.61(\mathrm{~m}, 8 \mathrm{H}) ; 8.29-8.26(\mathrm{~d}, J=8.0 \mathrm{~Hz}, 2 \mathrm{H}) ; 8.24-8.18(\mathrm{~m}, 6 \mathrm{H})$; $8.11-8.05(\mathrm{~d}, J=8.0 \mathrm{~Hz}, 2 \mathrm{H}) ; 7.90(\mathrm{~s}, 1 \mathrm{H}) ; 7.78-7.72(\mathrm{~m}, 9 \mathrm{H})$; $7.37-7.33(\mathrm{dd}, J=8.5 \mathrm{~Hz}, J=2.0 \mathrm{~Hz}, 1 \mathrm{H}) ; 7.31(\mathrm{~d}, J=2.0 \mathrm{~Hz}$, $1 \mathrm{H}) ; 6.96-6.93(\mathrm{~d}, J=8.5 \mathrm{~Hz}, 1 \mathrm{H}) ; 6.57(\mathrm{~s}, 1 \mathrm{H}) ; 5.70(\mathrm{~s}, 1 \mathrm{H})$; $4.64(\mathrm{~d}, 2 \mathrm{H}) ; 4.38-4.32(\mathrm{~m}, 2 \mathrm{H}) ; 4.20-4.02(\mathrm{~m}, 2 \mathrm{H}) ; 2.35-2.25$ $(\mathrm{m}, 1 \mathrm{H}) ; 1.52-1.48(\mathrm{~m}, 1 \mathrm{H}) ;-2.81(\mathrm{~s}, 2 \mathrm{H}) .{ }^{13} \mathrm{C}(125 \mathrm{MHz}$, $\left.\mathrm{CDCl}_{3}\right): \delta=25.7,29.7,43.9,67.5,102.9,117.8,118.5,120.3$, $125.3,126.5$ (x3), 126.7 (x3), 127.5 (x3) 127.7 (x3), 127.9, 129.2, $130.6,131.7,132.1,134.4$ (x2), 134.5, 134.6, 142.0, 142.7, 145.6, $150.3,155.0$. 


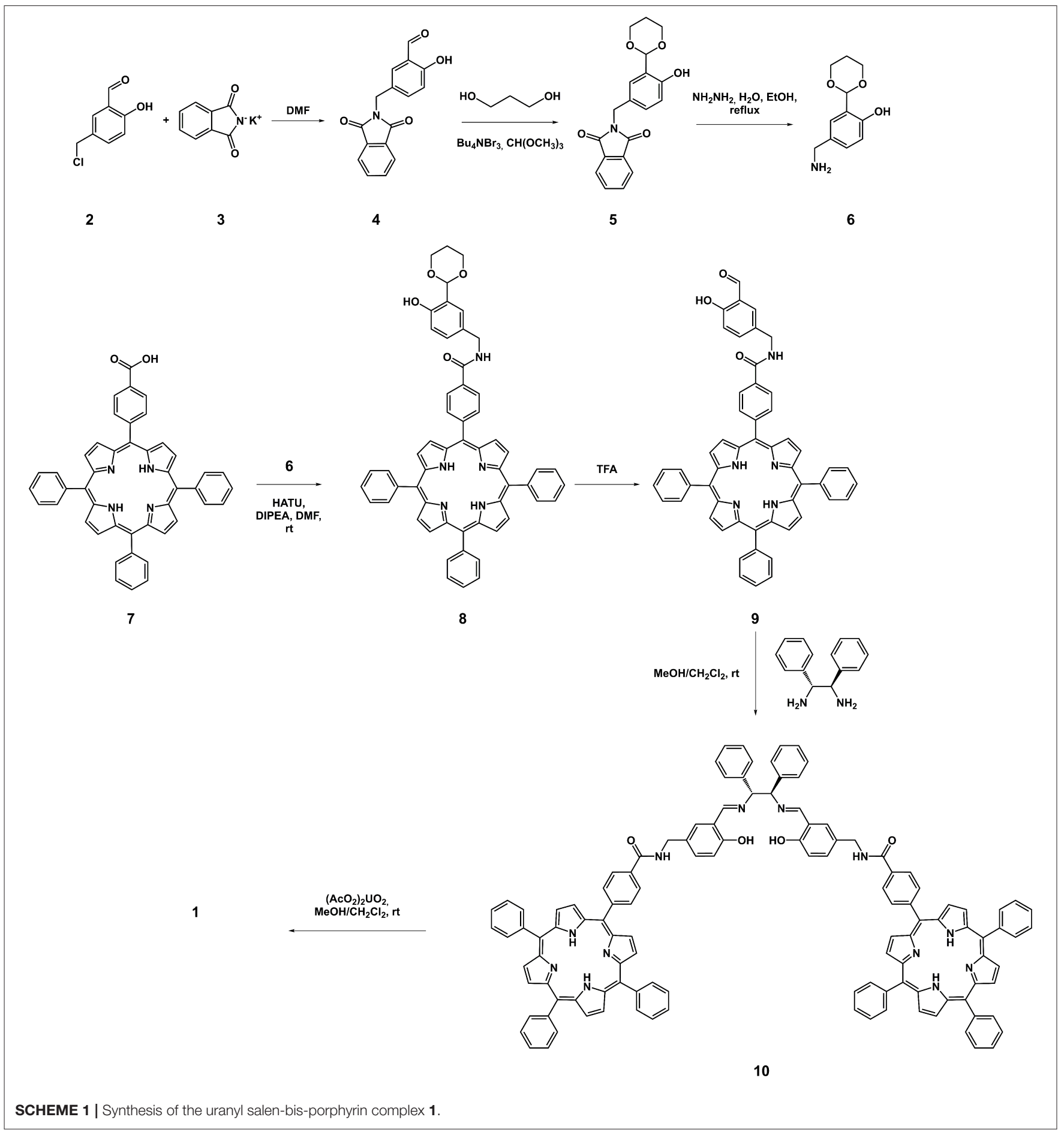

\section{Synthesis of Compound 9}

$0.080 \mathrm{~g}(0.094 \mathrm{mmmol})$ of compound 8 were dissolved in $1.74 \mathrm{~mL}$ of TFA, in a round-bottomed flask, and the resulting mixture was allowed to stir at room temperature for $3 \mathrm{~h}$. Then, $10 \mathrm{~mL}$ of diethyl ether were added to the organic solution affording a green precipitate, that was filtered and crystallized using $\mathrm{MeOH}$, to give $50 \mathrm{mg}$ (67\% yield) of a red solid. ${ }^{1} \mathrm{HNMR}\left(500 \mathrm{MHz}, \mathrm{CDCl}_{3}\right): \delta$ $=11.04(\mathrm{~s}, 1 \mathrm{H}) ; 9.96(\mathrm{~s}, 1 \mathrm{H}) ; 8.96-8.86(\mathrm{~m}, 8 \mathrm{H}) ; 8.33-8.29(\mathrm{~d}, J$ $=8.0 \mathrm{~Hz}, 2 \mathrm{H}) ; 8.24-8.19(\mathrm{~m}, 6 \mathrm{H}) ; 8.26-8.22(\mathrm{~d}, J=8.0 \mathrm{~Hz}, 2 \mathrm{H})$; 7.80-7.72 (m, 9H); $7.70(\mathrm{~d}, J=2.0 \mathrm{~Hz}, 1 \mathrm{H}) ; 7.68-7.64(\mathrm{dd}, J=$ $8.5 \mathrm{~Hz}, J=2.0 \mathrm{~Hz}, 1 \mathrm{H}) ; 7.05(\mathrm{~d}, J=8.5 \mathrm{~Hz}, 1 \mathrm{H}) ; 6.77(\mathrm{t}, 1 \mathrm{H}) ; 4.76$ $(\mathrm{d}, 2 \mathrm{H}) ;-2.77(\mathrm{~s}, 2 \mathrm{H}) .{ }^{13} \mathrm{C}\left(125 \mathrm{MHz}, \mathrm{CDCl}_{3}\right): \delta=43.0,118.0$, $118.1,120.4,121.2,125.0,125.2,126.5,126.7,127.5,127.8,128.5$, $129.0,131.4,132.1,132.2,132.6,132.8,132.9,134.4,134.5,134.6$, 
$136.6,136.7,142.0,142.8,149.5,150.1,150.3,150.4,167.2,196.3$. MS (ESI): $m / z=790.2[\mathrm{M}+\mathrm{H}]^{+}$.

\section{Synthesis of Salen-Bis-Porphyrin Ligand 10} In a round bottom flask, to a solution of $27.6 \mathrm{mg}$ of salicylic-porphyrin $9(0.0349 \mathrm{mmol})$ in absolute EtOH $(10 \mathrm{~mL})$ was added $(1 R, 2 R)-(+)-1,2$-diphenylethylendiamine $(3.7 \mathrm{mg}$, $0.0175 \mathrm{mmol})$. The reaction was stirred for $48 \mathrm{~h}$ at room temperature and monitored by TLC $\left(\mathrm{CH}_{2} \mathrm{Cl}_{2} / \mathrm{CH}_{3} \mathrm{OH}, 100: 2\right)$. The reaction was quenched by evaporation of the solvent under reduced pressure, and salen-bis-porphyrin ligand $\mathbf{1 0}$ was purified by PLC $\left(\mathrm{CH}_{2} \mathrm{Cl}_{2} / \mathrm{CH}_{3} \mathrm{OH}, 100: 2\right)$ to afford $24 \mathrm{mg}$ of a red/purple solid compound (78\% yield). ${ }^{1} \mathrm{HNMR}\left(500 \mathrm{MHz}, \mathrm{CDCl}_{3}\right): \delta=$ 14.41 (bs, $2 \mathrm{H}) ; 8.86-8.74(\mathrm{~m}, 16 \mathrm{H}) ; 8.30$ (s, 2H); 8.25-8.07 (m, $20 \mathrm{H}) ; 7.77-7.66(\mathrm{~m}, 20 \mathrm{H}) ; 7.29-7.15(\mathrm{~m}, 12 \mathrm{H}) ; 6.97(\mathrm{~d}, J=$ $8.5 \mathrm{~Hz}, 2 \mathrm{H}) ; 6.83(\mathrm{t}, 2 \mathrm{H}) ; 4.73$ (s, 2H); 4.56 (d, 4H); -2.78 (s, 4H). ${ }^{13} \mathrm{C}\left(125 \mathrm{MHz}, \mathrm{CDCl}_{3}\right): \delta=43.3,80.1,117.2(\mathrm{x} 2), 118.47,118.53$, 120.3 (x2), 120.5, 125.4 (x2), 126.3, 126.7 (x2), 127.7 (x3), 127.8 (x2), 128.4, 128.6, 131.0, 132.3, 133.5, 134.4 (x3), 134.5 (x2), 134.6, $139.0,141.9,142.0,145.6,160.4,166.2,167.4$. MS (ESI): $m / z=$ $1760.4[\mathrm{M}+\mathrm{H}]^{+}, m / z=891.0[\mathrm{M}+\mathrm{Na}]^{2+}$.

\section{Synthesis of Uranyl Salen-Bis-Porphyrin Complex 1}

To a solution of 10 (22 $\mathrm{mg}, 0.0125 \mathrm{mmol})$ dissolved in absolute ethanol $(10 \mathrm{~mL})$ was added uranyl acetate $(5.3 \mathrm{mg}, 0.0125 \mathrm{mmol})$. The reaction was stirred overnight at room temperature, and the resulting solid was filtered and dried to yield $27 \mathrm{mg}$ of uranyl salen-bis-porphyrin complex $\mathbf{1}$ as a red powder (98\% yield). ${ }^{1} \mathrm{HNMR}\left(500 \mathrm{MHz}, \mathrm{DMSO}-d_{6}\right): \delta=9.49(\mathrm{~s}, 2 \mathrm{H}) ; 9.33(\mathrm{~s}, 2 \mathrm{H})$ $8.82-8.76(\mathrm{~m}, 16 \mathrm{H}) ; 8.32-8.20(\mathrm{~m}, 20 \mathrm{H}) ; 7.83-7.80(\mathrm{~m}, 20 \mathrm{H})$; 7.74-7.59 (m, 8H); 7.21 (t, 2H); $7.15(\mathrm{~m}, 2 \mathrm{H}) ; 7.05$ (d, 2H); 6.35 (s, 2H); 4.67-4.57 (m, 4H); -2.93 (s, 4H). ${ }^{13} \mathrm{C}(125 \mathrm{MHz}$, DMSO$\left.d_{6}\right): \delta=42.2,79.5,119.0(\mathrm{x} 2), 120.1,120.2(\mathrm{x} 2), 120.3,122.7,125.9$ (x3), 126.6 (x2), 127.0 (x3), 127.2 (x2), 127.4 (x3), 127.5, 128.1, $128.2,133.7,133.9,134.2$ (x3), 135.2, 141.1, 141.6, 144.0, 166.0, 168.6, 171.2. MS (ESI): $m / z=1058[\mathrm{M}+2 \mathrm{EtOH}+2 \mathrm{H}]^{2+} ; m / z=$ $1077[\mathrm{M}+2 \mathrm{EtOH}+\mathrm{Na}+\mathrm{H}]^{2+}$.

\section{RESULTS AND DISCUSSION}

Target uranyl salen-bis-porphyrin complex 1 was synthesized in seven steps starting from 5-Cl-methyl-salycilaldheyde 2 (Dalla Cort et al., 2006; Saffar-Telur, 2015) as shown in Scheme 1. In the first step potassium phtalimide was treated with compound 2 to yield compound 4 (40\%), which was then reacted with 1,3-propandiol to afford the acetal intermediate 5 (92\%). Conversion of the phthalimido moiety into an amino group by treatment with hydrazine, under standard Gabriel conditions, yielded the compound 6 (57\%). The condensation reaction between compound 6 and 5-(4-Carboxyphenyl)10,15,20-triphenylporphyrin 7 (Gaware et al., 2017) which was activated using HATU (Gangemi et al., 2015), afforded the porphyrin derivative $8(16 \%)$, which was then treated with TFA to remove the acetal moiety and yield the salicylicporphyrin $9(67 \%)$. Condensation of 9 with the $(1 R, 2 R)-(+)-1,2-$ diphenylethylendiamine yielded salen ligand 10 (78\%), which was finally converted into the corresponding salen complex 1 (98 \%) by uranyl acetate. The proposed structures for this new chiral uranyl-salen complex and all the intermediates compounds are consistent with the ${ }^{1} \mathrm{H}$ and ${ }^{13} \mathrm{C} \mathrm{NMR}$ spectroscopy data as well as the ESI mass spectrometry data (see Supplementary Material).

The UV-vis spectrum of uranyl salen-bis-porphyrin complex 1 dissolved in $\mathrm{CHCl}_{3}$ solution shows an intense Soret band centered at $419 \mathrm{~nm}\left(\varepsilon=6,26 \cdot 10^{5} \mathrm{M}^{-1} \mathrm{~cm}^{-1}\right)$ and four Q-bands $(515 \mathrm{~nm} ; 550 \mathrm{~nm} ; 590 \mathrm{~nm} ; 646 \mathrm{~nm}$ ) (Figure 2). The UV-vis spectrum is similar to the 5-(4-Methoxycarbonylphenyl)10,15,20-triphenylporphyrin (TPPCOOMe, the precursor of 5-(4-Carboxyphenyl)-10,15,20-triphenylporphyrin 7) in the same solvent (Rong et al., 2012), suggesting that the insertion of the salen- $\mathrm{UO}_{2}$ does not change the spectroscopic behavior of the porphyrin. Furthermore, there is no evidence of aggregation even at higher concentration $(2.5 \mu \mathrm{M})$, as confirmed by UV-Vis and fluorescence data. In addition, the luminescence measurements are in accordance with literature data for similar porphyrins, with two main emission bands centered at 650 and $715 \mathrm{~nm}\left(\lambda_{\text {ex }}\right.$ $350 \mathrm{~nm}$ ), respectively (Figure 2).

After proving the luminescent properties of uranyl salenbis-porphyrin complex $\mathbf{1}$, enantioselective recognition properties were evaluated by UV-vis and fluorescence measurements in chloroform, in particular for fluorescence titrations, following the emission changes at these two emission wavelengths of porphyrin moiety $\left(650 \mathrm{~nm}\right.$ and $715 \mathrm{~nm}$, by using $\left.\lambda_{\text {ex }} 350 \mathrm{~nm}\right)$. Unfortunately, the fluorescence titrations showed a small intensity variation with all the selected amino acid guests except for the $L$-tryptophan derivative, which led to a poor data fitting. For that reasons, binding constant values between uranyl salen-bis-porphyrin complex $\mathbf{1}$ and amino acid derivatives were determined by UV-vis titrations, following a decrease of the absorption at $419 \mathrm{~nm}$ upon addition of increasing aliquots of guests. A representative example of UV-vis titration and the fluorescence titration of uranyl salen-bis-porphyrin complex $\mathbf{1}$ with L-Trp-TBA are shown in Figure 3.

Table 1 reports the pertinent binding constant values with selected amino acid derivatives, the detection limit observed (DL) and the corresponding enantiomeric excess. In all cases, binding constant values have been calculated using 1:1 stoichiometry, suggested by Job's plots (see Supplementary Material).

Notably, due to the presence of the porphyrin moieties, receptor $\mathbf{1}$ is able to detect the amino acid guests at low concentration. In fact, $1 \mu \mathrm{M}$ solution of uranyl salen-bisporphyrin complex $\mathbf{1}$ is able to detect amino acid derivatives at very low concentrations (ppb).

Enantiomeric recognition is very efficient with the $\boldsymbol{L}$-Phe-TBA, which is recognized more than 8 times respect to the $D$-enantiomer $\left(K_{L} / K_{D}=8.51\right)$. A good enantioselectivity is also observed for the $\boldsymbol{D}$ - and $\boldsymbol{L}$-Trp-TBA pair $\left(K_{D} / K_{L}=4.04\right)$. Moreover, for the $L$-Trp-TBA we were able to determine the binding constant value by fluorescence titration $\left(K\left(\mathrm{M}^{-1}=2.63\right.\right.$ $\left.\pm 0.03 \times 10^{6}\right)$, in good agreement with the value calculated by UV-vis titration. In particular, a decrease of the emission intensity has been observed, probably due to a photoinduced electron transfer mechanism (PET) (Trusso Sfrazzetto et al., 

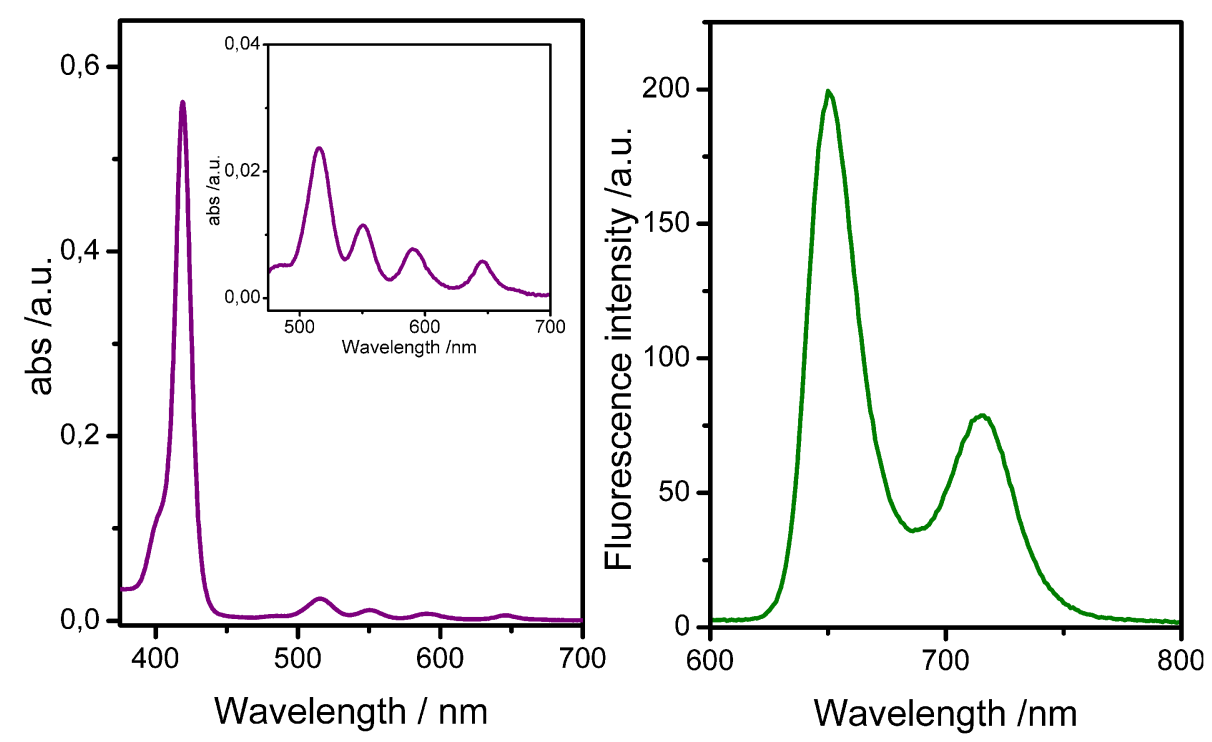

FIGURE 2 | UV-Vis spectra (Left) and fluorescence spectra (Right) of uranyl salen-bis-porphyrin complex $\mathbf{1}$ in $\mathrm{CHCl}_{3}(1 \mu \mathrm{M})$.

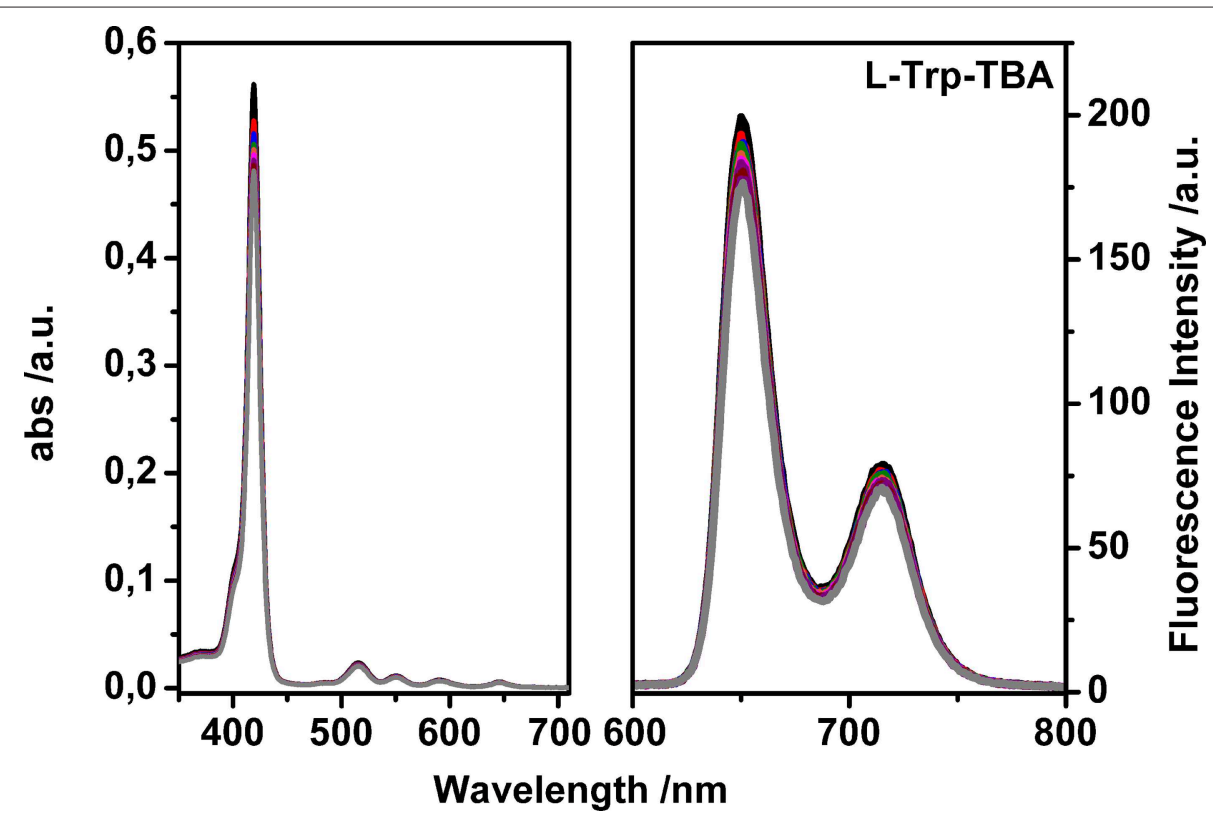

FIGURE 3 | Representative UV-vis titration (Left) and fluorescence titration (Right) of uranyl salen-bis-porphyrin complex $\mathbf{1}$ with $\boldsymbol{L}$-Trp-TBA $\left(\lambda_{\text {ex }}=350\right.$ nm in dry chloroform).

2016). Only the $\boldsymbol{D}$ - and $\boldsymbol{L}$-Ala-TBA $\left(K_{D} / K_{L}=1.70\right)$ pair shows a slight selective recognition. With the smaller amino acid guest, coordination to the uranyl metal center appears less susceptible to the different configurations of the carbon atom stereocenter and then the molecular recognition is less selective. With aromatic amino acid derivatives, the possibility for the carboxylate anion to bind the fifth equatorial coordination site of the uranyl metal and, at the same time, to exploit $\mathrm{CH}-\pi$ interactions with the salen moiety and the porphyrin macrocycles of receptor $\mathbf{1}$ might be responsible for the strong observed enantioselectivity. Moreover, the strong recognition for the $\mathbf{L}$-Phe-TBA enantiomer is in contrast with respect to those observed with our previous receptors having the same configuration of the chiral diamine bridge $(R, R)$ (Ballistreri et al., 2010; Amato et al., 2011; Pappalardo et al., 2012a; Forte et al., 2015). Probably, the presence of the two porphyrin arms not only increase the limit of detection by the presence of a fluorescence signal, but also plays a fundamental role in the recognition event. 
TABLE 1 | Binding constant values $K\left(\mathrm{M}^{-1}\right)$ with selected amino acid derivatives, detection limit observed (DL), and enantiomeric excess calculated by UV-vis titrations in dry chloroform at $25^{\circ} \mathrm{C}$.

\begin{tabular}{llll}
\hline Guest & $\mathbf{D L}^{\mathbf{b}}$ & $\boldsymbol{K} \mathbf{( M}^{-\mathbf{1}} \mathbf{)}^{\mathbf{a}}$ & e.e. \\
\hline D-Phe-TBA & $2.5 \mathrm{ppb}$ & $(8.13 \pm 0.08) \times 10^{4}$ & $K_{L} / K_{D}=8.51$ \\
L-Phe-TBA & $1.6 \mathrm{ppb}$ & $(6.92 \pm 0.07) \times 10^{5}$ & \\
D-Ala-TBA & $1.7 \mathrm{ppb}$ & $(9.77 \pm 0.59) \times 10^{6}$ & $K_{D} / K_{L}=1.70$ \\
L-Ala-TBA & $1.3 \mathrm{ppb}$ & $(5.75 \pm 0.05) \times 10^{6}$ & \\
D-Trp-TBA & $1.6 \mathrm{ppb}$ & $(4.33 \pm 0.09) \times 10^{6}$ & $K_{D} / K_{L}=4.04$ \\
L-Trp-TBA & $1.1 \mathrm{ppb}$ & $(1.07 \pm 0.01) \times 10^{6}$ & \\
\hline
\end{tabular}

${ }^{a}$ Calculated by HypSpec v1.1.33.

${ }^{b}$ Caculated by method of the calibration curve using the formula $D L=3 \sigma / K$, where $\sigma$ is the standard deviation of the blank, and $K$ is the slope of the calibration curve.

\section{CONCLUSION}

We have synthesized a new chiral uranyl salen complex bearing two porphyrin macrocycles and evaluated the enantiomeric recognition properties of this complex toward $\alpha$-amino acid derivatives by UV-vis titrations. The presence of porphyrin arms lead to a receptor that possesses luminescence properties that are not quenched by the coordination with the uranyl cation, which decreases the fluorescence intensity in uranyl salen complexes. UV/Vis measurements and Job plots indicate the formation of 1:1 host-guest complexes. This receptor displays a very high selectivity toward amino acid derivatives, in particular for the two enantiomers of Phe-TBA. The two porphyrin macrocycles play a key role in the enantioselectivity interacting through

\section{REFERENCES}

Amato, M. E., Ballistreri, F. P., D’Agata, S., Pappalardo, A., Tomaselli, G. A., Toscano, R. M., et al. (2011). Enantioselective molecular recognition of chiral organic ammonium ions and amino acids using cavitand-salenbased receptors. Eur. J. Org. Chem. 21, 5674-5680. doi: 10.1002/ejoc. 201100955

Amato, M. E., Ballistreri, F. P., Gentile, S., Pappalardo, A., Tomaselli, G. A., and Toscano, R. M. (2010). Recognition of achiral and chiral ammonium salts by neutral ditopic receptors based on chiral salen- $\mathrm{UO}_{2}$ macrocycles. J. Org. Chem. 75, 1437-1443. doi: 10.1021/jo902328y

Amato, M. E., Ballistreri, F. P., Pappalardo, A., Sciotto, D., Tomaselli, G. A., and Toscano, R. M. (2007). Synthesis and conformational aspects of 20 - and 40-membered macrocyclic mono and dinuclear uranyl complexes incorporating salen and (R)-BINOL units. Tetrahedron 63, 9751-9757. doi: 10.1016/j.tet.2007.07.014

Baleizao, C., and Garcia, H. (2006). Chiral salen complexes: an overview to recoverable and reusable homogeneous and heterogeneous catalysts. Chem. Rev. 106, 3987-4043. doi: 10.1021/cr050973n

Ballistreri, F. P., Gangemi, C. M., Pappalardo, A., Tomaselli, G. A., Toscano, R. M., and Trusso Sfrazzetto, G. (2016). (Salen)Mn(III) catalyzed asymmetric epoxidation reactions by hydrogen peroxide in water: a green protocol. Int. J. Mol. Sci. 17:1112. doi: 10.3390/ijms17071112

Ballistreri, F. P., Lombardo, G., Pappalardo, A., Punzo, F., Thompson, A., Tomaselli, G. A., et al. (2012). An integrated X-ray and molecular dynamics study of uranyl-salen structures and properties. Dalton Trans. 41, 1951-1960. doi: 10.1039/C1DT11758K

Ballistreri, F. P., Pappalardo, A., Toscano, R. M., Tomaselli, G. A., and Trusso Sfrazzetto, G. (2010). Heteroditopic chiral uranyl-salen receptor for molecular
$\mathrm{CH}-\pi$ with the aromatic moiety of aminoacids, leading to high binding affinities. Work is in progress in our laboratory to better understand the rules governing the interactions of this salen receptor with amino acid guests in order to design new hostguest systems that possess luminescence properties.

\section{DATA AVAILABILITY STATEMENT}

All datasets generated for this study are included in the article/Supplementary Material.

\section{AUTHOR CONTRIBUTIONS}

CG, UR, FC, and AP performed the synthesis of uranyl porphyrin-salen complex. GT acquired UV-vis and luminescence data. AP writing-original draft preparation. CG, UR, FC, GT, and AP writing-review and editing.

\section{FUNDING}

This work was supported by the University of Catania, Department of Chemical Sciences (Piano per la Ricerca 20162018-Linea Intervento 2).

\section{SUPPLEMENTARY MATERIAL}

The Supplementary Material for this article can be found online at: https://www.frontiersin.org/articles/10.3389/fchem. 2019.00836/full\#supplementary-material

recognition of amino acid ammonium salts. Eur. J. Org. Chem. 20, 3806-3810. doi: 10.1002/ejoc.201000566

Ballistreri, F. P., Toscano, R. M., Amato, M. E., Pappalardo, A., Gangemi, C. M. A., Spidalieri, S., et al. (2018). A new Mn-salen micellar nanoreactor for enantioselective epoxidation of alkenes in water. Catalysts 8:129. doi: 10.3390/catal8040129

Beletskaya, I., Tyurin, V. S., Tsivadze, A. Y., Guilard, R., and Stern, C. (2009). Supramolecular chemistry of metalloporphyrins. Chem. Rev. 109, 1659-1713. doi: $10.1021 / \mathrm{cr} 800247 \mathrm{a}$

Brancatelli, G., Geremia, S., Notti, A., Pappalardo, A., and Trusso Sfrazzetto, G. (2013). Mono- and dinuclear uranyl(VI) complexes with chiral Schiff base ligand. Inorg. Chim. Acta 396, 25-29. doi: 10.1016/j.ica.2012.12.034

Cozzi, P. G. (2004). Metal-Salen Schiff base complexes in catalysis: practical aspects. Chem. Soc. Rev. 33, 410-421. doi: 10.1039/B307853C

Dalla Cort, A., Mandolini, L., Pasquini, C., and Schiaffino, L. (2006). A novel ditopic zinc-salophen macrocycle: a potential two-stationed wheel for [2]pseudorotaxane. Org. Biomol. Chem. 4, 4543-4546. doi: 10.1039/b613705a

Drain, C. M., Varotto, A., and Radiovojevic, I. (2009). Self-organized porphyrinic materials. Chem. Rev. 109, 1630-1658. doi: 10.1021/cr8002483

D’Urso, A., Tudisco, C., Ballistreri, F. P., Condorelli, G. G., Randazzo, R., Tomaselli, G. A., et al. (2014). Enantioselective extraction mediated by a chiral cavitand-salen covalently assembled on a porous silicon surface. Chem. Commun. 50, 4993-4496. doi: 10.1039/C4CC00034J

Forte, G., D’Urso, A., Ballistreri, F. P., Toscano, R. M., Tomaselli, G. A., Trusso Sfrazzetto, G., et al. (2015). Enantiomeric recognition of $\alpha$-amino acid derivatives by chiral uranyl-salen receptors. Tetrahedron Lett. 56, 2922-2926. doi: 10.1016/j.tetlet.2015.04.092

Gangemi, C. M. A., Randazzo, R., Fragal,à, M. E., Tomaselli, G. A., Ballistreri, F. P., Pappalardo, A., et al. (2015). Hierarchically controlled 
protonation/aggregation of a porphyrin-spermine derivative. New J. Chem. 39, 6722-6725. doi: 10.1039/C5NJ01264C

Gaware, V. S., Hakerud, M., Juzeniene, A., Høgset, A., Berg, K., and Másson, M. (2017). Endosome targeting meso-tetraphenylchlorin-chitosan nanoconjugates for photochemical internalization. Biomacromolecules 18, 1108-1126. doi: 10.1021/acs.biomac.6b01670

Jacobsen, E. N. (1993). “Asymmetric catalytic epoxidation of unfunctionalized olefins," in Catalytic Asymmetric Synthesis, ed I. Ojima (New York, NY: VCH), 159-202.

Jacobsen, E. N. (2000). Asymmetric catalysis of epoxide ring-opening reactions. Acc. Chem. Res. 33, 421-431. doi: 10.1021/ar960061v

Johansson, A., Abrahamsson, M., Magnuson, A., Huang, P., Mårtensson, J., Styring, S., et al. (2003). Synthesis and photophysics of one mononuclear $\mathrm{Mn}$ (III) and one dinuclear $\mathrm{Mn}$ (III,III) complex covalently linked to a ruthenium(II) tris(bipyridyl) complex. Inorg. Chem. 42, 7502-7511. doi: $10.1021 /$ ic0344822

Katsuki, T. (1995). Catalytic asymmetric oxidations using optically active (salen)manganese(III) complexes as catalysts. Coord. Chem. Rev. 140, 189-214. doi: 10.1016/0010-8545(94)01124-T

Katsuki, T. (2000). "Asymmetric oxidations and related reactions: asymmetric epoxidation of unfunctionalized olefins and related reactions," in Catalytic Asymmetric Synthesis, 2nd Edn, ed I. Ojima (New York, NY: WileyVCH), 287-325.

La Paglia Fragola, V., Lupo, F., Pappalardo, A., Trusso Sfrazzetto, G., Toscano, R. M., Ballistreri, F. P., et al. (2012). A surface-confined $\mathrm{O}=\mathrm{MnV}$ (salen) oxene catalyst and high turnover values in asymmetric epoxidation of unfunctionalized olefins. J. Mater. Chem. 22, 20561-20561. doi: $10.1039 / \mathrm{c} 2 \mathrm{jm} 34847 \mathrm{k}$

McGarrigle, E. M., and Gilheany, D. G. (2005). Chromium- and manganesesalen promoted epoxidation of alkenes. Chem. Rev. 105, 1563-1602. doi: $10.1021 / \mathrm{cr} 0306945$

Pappalardo, A., Amato, M. E., Ballistreri, F. P., Tomaselli, G. A., Toscano, R. M., and Trusso Sfrazzetto, G. (2012a). Pair of diastereomeric uranyl salen cavitands displaying opposite enantiodiscrimination of $\alpha$-amino acid ammonium salts. J. Org. Chem. 77, 7684-7687. doi: 10.1021/jo301098d

Pappalardo, A., Ballistreri, F. P., Li Destri, G., Mineo, P. G., Tomaselli, G. A., Toscano, R. M., et al. (2012b). Supramolecular polymer networks based on calix[5]arene tethered poly(p-phenyleneethynylene). Macromolecules 45, 7549-7556. doi: 10.1021/ma3015239

Puglisi, R., Ballistreri, F. P., Gangemi, C. M. A., Toscano, R. M., Tomaselli, G. A., Pappalardo, A., et al. (2017). Chiral Zn-salen complexes: a new class of fluorescent receptors for enantiodiscrimination of chiral amines. New J. Chem. 41, 911-915. doi: 10.1039/C6NJ03592B

Puglisi, R., Mineo, P. G., Pappalardo, A., Gulino, A., and Trusso Sfrazzetto, G. (2019). Supramolecular detection of a nerve agent simulant by fluorescent $\mathrm{Zn}$-salen oligomer receptors. Molecules 24:2160. doi: 10.3390/molecules 24112160
Puglisi, R., Pappalardo, A., Gulino, A., and Trusso Sfrazzetto, G. (2018). Supramolecular recognition of CWAs simulant by metal-salen complexes: the first multi-topic approach. Chem. Commun. 54, 11156-11159. doi: 10.1039/C8CC06425C

Rong, Y., Chen, P., Wang, D., and Liu, M. (2012). Porphyrin assemblies through the air/water interface: effect of hydrogen bond, thermal annealing, and amplification of supramolecular chirality. Langmuir 28, 6356-6363. doi: 10.1021/la3005294

Saffar-Telur, A. (2015). Direct covalent attachment of Mn(III) salophen complex to the hydroxyapatite-encapsulated $\gamma-\mathrm{Fe}_{2} \mathrm{O}_{3}$ nanocrystallites: an efficient magnetic and reusable catalyst for oxidation of alcohols. RSC Adv. 5, 70577-70585. doi: 10.1039/C5RA08594B

Trusso Sfrazzetto, G., Millesi, S., Pappalardo, A., Toscano, R. M., Ballistreri, F. P., Tomaselli, G. A., et al. (2015). Olefin epoxidation by a (salen)Mn(III) catalyst covalently grafted on glass beads. Cat. Sci. Techn. 5, 673-679. doi: 10.1039/C4CY00831F

Trusso Sfrazzetto, G.; Satriano, C.; Tomaselli, G. A.; and Rizzarelli, E. (2016). Synthetic fluorescent probes to map metallostasis and intracellular fate of zinc and copper. Coord. Chem. Rev. 311, 125-167. doi: 10.1016/j.ccr. 2015.11.012

Wezenberg, S. J., and Kleij, A. W. (2008). Material applications for salen frameworks. Angew. Chem., Int. Ed. 47, 2354-2364. doi: 10.1002/anie.200702468

Whiteoak, C. J., Salassa, G., and Kleij, A. W. (2012). Recent advances with $\pi$-conjugated salen systems. Chem. Soc. Rev. 41, 622-631. doi: 10.1039/C1CS15170C

Yoon, T. P., and Jacobsen, E. N. (2003). Privileged chiral catalysts. Science 299, 1691-1693. doi: 10.1126/science. 1083622

Zammataro, A., Gangemi, C. M. A., Pappalardo, A., Toscano, R. M., Puglisi, R., Nicotra, G., et al. (2019). Covalently functionalized carbon nanoparticles with a chiral Mn-Salen: a new nanocatalyst for enantioselective epoxidation of alkenes. Chem. Commun. 55, 5255-5258. doi: 10.1039/C9CC01825E

Conflict of Interest: The authors declare that the research was conducted in the absence of any commercial or financial relationships that could be construed as a potential conflict of interest.

The reviewer SG declared a past co-authorship with one of the authors AP to the handling editor.

Copyright (c) 2019 Gangemi, Rimkaite, Cipria, Trusso Sfrazzetto and Pappalardo. This is an open-access article distributed under the terms of the Creative Commons Attribution License (CC BY). The use, distribution or reproduction in other forums is permitted, provided the original author(s) and the copyright owner(s) are credited and that the original publication in this journal is cited, in accordance with accepted academic practice. No use, distribution or reproduction is permitted which does not comply with these terms. 